\title{
THE EFFECT OF SNAKES AND LADDERS GAME TO IMPROVE KNOWLEDGE AND ATTITUDES OF ELEMENTARY SCHOOL STUDENTS TO STOP OPEN DEFICATION IN BANDUNG CITY
}

\author{
Miki Kurnia Fitrizah ${ }^{1}$, Ardini S. Raksanagara ${ }^{2}$, Ridad Agoes ${ }^{2}$ \\ ${ }^{1}$ Public Health Sciences Study Program STIKes Bhakti Husada Bengkulu, Bengkulu, Indonesia \\ ${ }^{2}$ Department of Public Health Sciences, Faculty of Medicine, Padjadjaran University, Jawa Barat, Indonesia \\ Correspondence Address: Miki Kurnia Fitrizah \\ E - mail : mikifitrizah@gmail.com
}

\begin{abstract}
Knowledge and attitude may increase by using a interesting, convenient, and simple health promotion method or media, for instance, a snake and ladder game. This study measured and analyzed the effectiveness of snake and ladder game to increase elementary school students' knowledge and attitude on how to stop open defication. This research performed a true experiment approach with two-group pre-test post-test design. There were 62 respondents divided into 31 respondents in the control group and 31 respondents in the control group. This study distributed questionnaires to the respondents. Data were analyzed using the R Commander program. The results indicated that there were significant differences in the improvement of knowledge and attitude before and after given the intervention of the snake and ladder game about stopping open defication $(\mathrm{P}=0.0001$ for knowledge, $\mathrm{P}=0.0001$ for attitude). In the control group, there were significant differences in knowledge and attitude level before and after triggering $(\mathrm{P}=0.0001$ for knowledge, $\mathrm{P}=0.0001$ for attitude). The control and experiment groups showed no effectiveness difference in $(\mathrm{P}=0.556, \mathrm{P}=0.226)$. The provision of health education through both snake and ladder game and triggering method impacted on improving knowledge and attitude of elementary school students. The snake and ladder game can be used as an alternative health education tool at schools.
\end{abstract}

Keywords: snack and ladder game, triggering, knowledge, attitude.

\section{ABSTRAK}

Peningkatan pengetahuan dan sikap pada siswa sekolah dasar dapat dilakukan dengan bantuan metode atau media promosi kesehatan yang menarik, mudah, dan sederhana seperti media permainan edukatif ular tangga. Penelitian ini menganalisis pengaruh permainan ular tangga terhadap peningkataan pengetahuan dan sikap tentang Stop Buang Air Besar Sembarangan (BABS) pada siswa sekolah dasar. Penelitian ini menggunakan pendekatan true experiment dengan rancangan two group pre-test-post-test. Jumlah sampel dalam penelitian ini adalah 62 responden, 31 responden pada kelompok permainan ular tangga dan 31 pada kelompok pemicu dengan menyebarkan kuesioner. Data dianalisis menggunakan uji $R$ berpasangan. Hasil penelitian menunjukkan adanya peningkatan pengetahuan $(P=0,0001)$ dan sikap $(P=0,0001)$ setelah diberikan intervensi permainan ular tangga. Sedangkan, pada kelompok pemicu terdapat peningkatan pengetahuan $(P=0,0001)$ dan sikap $(P=0,0001)$ sesudah diberikan pendidikan kesehatan. Tidak terdapat perbedaan pengaruh antara kelompok eksperimen dengan kelompok kontrol sesudah diberikan pendidikan kesehatan $(P=0,224, P=0,552)$. Permainan ular tangga dan pemicu sama-sama memiliki pengaruh terhadap peningkatan pengetahuan dan sikap siswa. Permainan ular tangga dapat dijadikan media pendidikan kesehatan alternatif di lingkungan sekolah.

Kata kunci: permainan ular tangga, pemicuan, pengetahuan, sikap.

\section{INTRODUCTION}

The lack of public awareness of hygiene and health is a major triggering factor unresolved by the Indonesian government. Health problems mutually occur with other problems beyond health issues itself. Solving public health problems may include not only the health aspects but also other aspects that affect "healthy pain" or health, such as access to decent sanitation as one of the cores of healthy society. Basic sanitation problems include the means of disposal of feces/human waste, waste 
management and household wastes, which have not become priorities for the Indonesian government both in rural and urban (Ministry of Health, 2010)

Poor sanitation gives bad impacts on the environment including the declining ecosystem quality, pollution of water sources, increased cases of diarrhea and other diseases especially in infants, and decline in economy in different regions. One of health problems due to poor basic sanitation is diarrheal disease (Ministry of Health, 2013).

Data showed the number of infants with diarrhea in Bandung city was 39,295 cases in 2011, 49,322 cases in 2012, 25,361 cases in 2013, 24,370 cases in 2014, and 23,827 cases in 2015 . on the number of diarrhea cases in Tamansari Primary Healthcare Center increased in 2014 as many as 972 . In 2015, this increased up to 1158. The percentage of patients with diarrhea was $201.59 \%$ in Mandalajati subdistrict, $220.19 \%$ in Panyileukan subdistrict and 229.71\% Bandung Wetan subdistrict, respectively (Bandung District of Public Health Office, 2015).

The diarrhea cases are closely related to healthy living behaviors of individuals and the environment. Risks of polluted water sources and the means of latrines also cause diarrhea. One example of behaviors that affects the level of public health is a bowel habit.

The 2016 health profile of Tamansari Primary Healthcare Center mentioned that of 1660 houses inspected, there were 129 the family's latrines with complete septic tank $(7.8 \%)$ The majority of the latrines $(82 \%)$ had no septic tank, while only $35.56 \%$ had good sanitation" (Tamansari of Primary Health Center, 2016). Tamansari village is an urban slum located in Bandung near to Cikapundung river, and $10.57 \mathrm{~km}$ of the area mostly becomes residence. People utilize Cikapundung river for household stool and fluid waste by attaching pipes as a drain to the river body, and as much as 2.5 million liters/day pass the river (Tamansari, 2015).
The community-based sanitation program is a strategy conducted and established by the government to address the problems.

"School-based health education is very important because children can bring change in society and play an important role to form better behavior in their family. Due to their roles, knowledge of health that they learn at schools will positively impact on their attitudes and behavior" (Gunarsa, 2008).

When they begin the school period, the school environment will provide a core experience to the child. In this period, children will learn how to be responsible for their own behavior towards their parents, peers, and even others. Childhood becomes the foundation of gaining knowledge for future self-adjustment to adulthood and acquisition of certain skills.

Research conducted by (Lucie, 2006) found that elementary-school age is a critical since children have a high physical activity but do not have enough knowledge about health and thus become the most vulnerable to disease. According to (Kar, 2005) the habit of open defication is the result of less healthy behavior and poor sanitation.

Health education about how to stop open defication can be delivered using appropriate and acceptable methods and right tools. The triggering method is commonly applied for changing hygiene behavior in the community. Behavior change in hygiene and sanitation becomes the aim of the Community Based Total Sanitation program by intervening the society's mindset, behaviors, and habits (Departement of Health, 2008)

Triggering activities conducted in the community environment still have some weaknesses and shortcomings, including complicated technical implementation, and a large amount of cost. When applied to elementary-school children, these activities have not optimally been performed. Furthermore, some educational games have too many elements that can not be played independently; hence, a simple understable 
entertaining method or a health educational media that allow students to engage in is required. Here, the researchers developed a health promotion tool foe school-based health education, i.e., Snakes and Ladders Stop Open Defication.

Snakes and ladders is a model of health education that has never been used widely for students, especially in elementary school in Tamansari village. This game was designed by adopting some theories about a good bowel habit, such as understanding the impact of how to stop open defication and the utilization of healthy latrines. Snake and ladder game was selected as the educative media because it presented a variety of images in boxes. This game consists of a single sheet of paper with a 36 pictures, pawns and dice. This game was aimed to improve knowledge and attitudes of students about how to stop open defication and healthy life style. Research conducted by (Hamdalah, 2013) found knowledge and attitude could be influenced by types of media used in the learning process. Providing health education through this game was expected to improve knowledge and attitudes of students to have healthy life style, especially with regards to stop open defication. This game generally can be used not only at school but also the community.

From the background of the problem, this study analyzed the effect of snakes and ladders game on knowledge and attitude of elementary-school students about how to stop open defication in Bandung city.

\section{METHODS}

The study performed a quantitative design with the true experimental approach and pre-test post-test design. The population was all elementary school students in grade $5^{\text {th }}$ in Tamansari village, Bandung. The experiment group was intervened using a snakes and ladders game, while the control group was given triggering activities. Each group consisted of 31 people selected by purposive sampling. This study was conducted in February to April 2017 in Tamansari village, Bandung. The students should be aged 9-12 years, in the fifth grade, and willing to participate in this study. The students who were absent during the data collection were excluded from the list of respondents. In this study, both groups were given health education to stop open defication and were evaluated after 15-30 days.

Quantitative data were collected from the scores of pre-tests and post-test from knowledge and attitude questionnaires. In the questionnaire, knowledge level was measured from 18 multiple-choice questions with 3 answer options which only has 1 correct answer. Each correct answer worths 1 point, and the maximum score was 18 points. While, tattitude was scored in a Likert scale with positive and negative categories. The questionnaires were formed from various relevant sources and tested for its validity and reliability.

The data were then proceeded using univariate analysis to find the distribution and percentage of each variable, such as age and gender. While, bivariate analysis was used to look for statistical differences in knowledge level and and attitude before and after treatment using paired T-test. Variables in this study were the nominal measurement scale and interval. Hence, the ranked nonparametric Wilcoxon Rank-Sum Test was employed. This study obtained the ethical clearance from the Universitas University Ethics Commission with No: 127/UN6. C. 1.3.2/KEPK/PN/2017.

\section{RESULT}

\section{Characteristics of respondents}

According to Table 1, the frequency distribution of respondents by gender shows 37 male respondents $(59.68 \%)$ and 25 females (40.32\%). By age, of 62 respondents, 15 respondents $(24.19 \%)$ were 10 years old, 35 respondents $(56.45 \%)$ were 
11 years old, and 12 respondents $(19.36 \%)$ were 12 years old.

Table 1. Frequency distribution of respondents based on gender and age

\begin{tabular}{|c|c|c|c|c|c|c|}
\hline \multirow{3}{*}{ Characteristics } & \multicolumn{4}{|c|}{ Group } & \multirow{3}{*}{$\mathrm{n}$} & \multirow{3}{*}{$\%$} \\
\hline & \multicolumn{2}{|c|}{ Control } & \multicolumn{2}{|c|}{$\begin{array}{c}\text { Experimen } \\
\text { t Group }\end{array}$} & & \\
\hline & $\mathbf{n}$ & $\%$ & $\mathbf{n}$ & $\%$ & & \\
\hline \multicolumn{7}{|l|}{ Gender } \\
\hline Male & 21 & 67.74 & 16 & 51.62 & 37 & 59,68 \\
\hline Women & 10 & 32.26 & 15 & 48.38 & 25 & 40,32 \\
\hline \multicolumn{7}{|l|}{ Age } \\
\hline 10 years old & 9 & 29.03 & 6 & 19.35 & 15 & 24,19 \\
\hline 11 years old & 16 & 51.61 & 19 & 61.29 & 35 & 56,45 \\
\hline \multirow{2}{*}{$\begin{array}{l}12 \text { years old } \\
\text { Total }\end{array}$} & 6 & 19.35 & 6 & 19.35 & 12 & 19,36 \\
\hline & 31 & 100 & 31 & 100 & 62 & 100 \\
\hline
\end{tabular}

\section{Univariat Analysis}

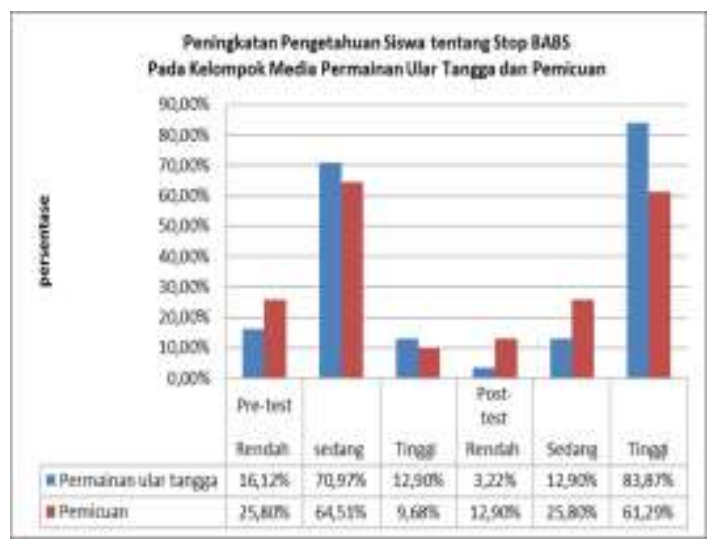

Figure 1. Improvement in knowledge in the experiment group

The level of knowledge before and after the experiment group was given an intervention increased. The pre-test figured out 5 respondents had increased knowledge $(16.12 \%)$, and only 11 respondent had decreased knowledge (3.22\%). In the posttest, 4 respondents (70.97) experienced decreased knowledge (12.90\%), while 26 respondents (12.90) improved their knowledge (83.87\%). Meanwhile, the number of respondents with low knowledge decreased $(12.90 \%)$, but those with high knowledge increased up to 19 respondents $(64.51 \%)$.

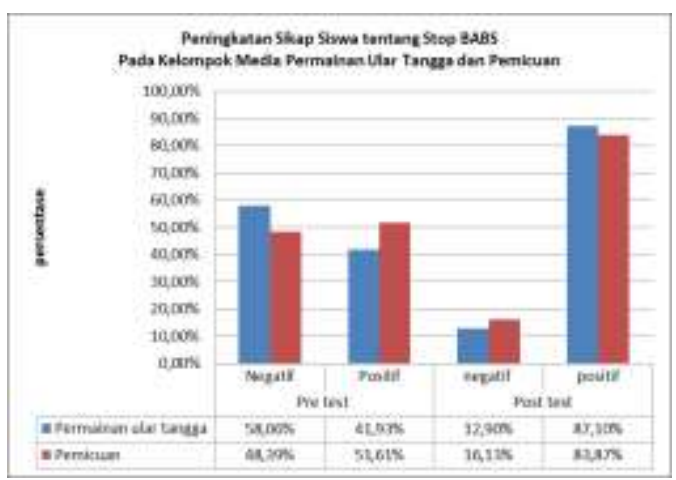

Figure 2. Improved attitude in the experiment group

Figure 2 displays there is an increase in attitude during pre-test and post-test. In the post-test of the experiment group, there were 4 respondents with negative attitudes $(12.90 \%)$, while the number of those with positive attitudes increased to $27(87.10 \%)$. The control group showed 5 respondents had negative attitudes $5(16.13 \%)$, and 26 respondents $(83.87 \%)$ showed positive attitudes.

\section{Bivariat Analysis}

Table 2. Differences in knowledge and attitudes of students about Stop BABS before and after being given a game of snakes and Ladders

\begin{tabular}{|c|c|c|c|c|}
\hline \multirow[t]{2}{*}{ Variable } & \multicolumn{2}{|c|}{$\begin{array}{c}\text { Experiment } \\
\text { Group }\end{array}$} & \multicolumn{2}{|c|}{$\begin{array}{l}\text { Control } \\
\text { Group }\end{array}$} \\
\hline & $\mathbf{N}$ & P value & $\mathbf{N}$ & P value \\
\hline \multicolumn{5}{|l|}{ Knowlegde } \\
\hline Pre-test & 31 & \multirow{2}{*}{0.0001} & 31 & \multirow{2}{*}{0.0001} \\
\hline Post-test & 31 & & 31 & \\
\hline \multicolumn{5}{|l|}{ Attitude } \\
\hline Pre-test & 31 & & 31 & \\
\hline Post-test & 31 & 0.0001 & 31 & 0.0001 \\
\hline
\end{tabular}

Table 2 informs the effect of snakes and ladders game showed a meaningful difference to the increase in knowledge with $\mathrm{P}$-value of $0.0001(<\mathrm{P}=0.05)$. Likewise, the control group showed a meaningful difference of improved attitude with $\mathrm{P}$-value of $0.0001(<\mathrm{P}=0.05)$. In the control group, there was a meaningful 
difference in knowledge with $\mathrm{P}$-value of $0.0001(<\mathrm{P}=0.05)$, while the increase in attitude showed a meaningful difference with $\mathrm{P}$-value of $0.0001(<\mathrm{P}=0.05)$.

Table 3. Effectiveness of increasing knowledge and attitude between the control group and experiment group

\begin{tabular}{lccc}
\hline Variable & Method & n & p value \\
\hline Knowlegde & $\begin{array}{c}\text { Snakes and } \\
\text { Ladders }\end{array}$ & 31 & 0,556 \\
& Trigger & 31 & \\
\hline Attitude & $\begin{array}{c}\text { Snakes and } \\
\text { Ladders }\end{array}$ & 31 & \\
& Trigger & 31 & 0,255 \\
\hline
\end{tabular}

Table 3 shows that there was no difference in the effectiveness of the intervention given to increase knowledge about how to stop open defication with Pvalue of 0.556 ( $>\mathrm{P}=0.05$ ). In addition, there was no difference in the effectiveness of the intervention to improve attitude between the control group and experimental group with $\mathrm{P}$-value 0.255 ( $>\mathrm{P}=0.05)$. It can be concluded that snakes and ladders game was influential in improving students' knowledge and attitudes about stopping open defication.

\section{DISCUSSION}

The snakes and ladders game was given once to increase knowledge and attitude about how to stop open defication in elementary school students. It was corresponded with a study in the UK which mentioned that educative toys were proven to be effective in supporting learning, especially improving knowledge (Blakely G, 2010) According to (Green, 1992), attitudes, beliefs, opinions, and information ever gained are the predisposition factors that can affect knowledge.

Increase in knowledge through triggering occurred because the respondents were involved directly in the activities and interacted with each other. Given this method, the respondents were given a chance to speak up their opinion and conditions in the surrounding, discuss how to stop open defication among fellow students so that they understand the impacts of open defication and healthy life style. This method also allows them to become agents of change in their family, especially who do not have healthy latrines. The research of (Pudjaningrum 2016) found health education through triggering could give a significant difference in the increase in knowledge, attitudes and practices of stopping open defication in the community.

Snakes and ladders game is a health education media that contains messages and information about how to stop open defication. It is supported with a variety of interesting images that correspond to the topics given. Subsequently, both the control and experiment groups improve their knowledge and attitudes. However, the experiment group that had snakes and ladders play had higher increase in knowledge of $83.87 \%$ and $87.10 \%$ for pretest and post-test, respectively. While, an increase of $61.29 \%$ and $83.87 \%$ in knowledge belongs to the control group.

These findings were supported by a study of (Siyam, 2015), indicating snake and ladder game could increase knowledge with $11.06 \%$ and a standard deviation of 2.58 in the pre-test and 13.01 with a standard deviation value of 2.73 in the posttest among children aged aged 8-11 years.

The snakes and ladders game showed equal improvement of knowledge and attitudes. The intensity of attention or willingness to listen to what the researchers delivered are the keys to change the respondents' knowledge. Reduced attention did not make any change in knowledge despite the health education activities.. In this study, both the groups experienced increased knowledge since the respondents firstly encountered both methods of triggering and snakes and ladders game at school. It turned out to make them give more attention and enthusiasm.

Besides, playing can give the stimulus for child's curiosity and interest 
that allow them to see, move, and interact with each other. Attractive and understandable images on the snakes and ladders game were designed with acceptable rules and look. Stated the game could give fun and interesting atmosphere for the players (Pratiwi 2016) also found an increase in knowledge and attitudes of students about environmental health showed a score difference after the snakes and ladders game was given.

In educating children about health education, the snakes and ladders game has advantages over triggering. This game is more practical for presentation and easy to play and store in large or small groups. Proper educational media could achieve the objectives of health education for elementary school. In the snakes and ladders game, the students learned to use their five senses such as sight, hearing and touch They used their visual sense by looking at some pictures on it. They also read what is stated on the cards and touched the pawn from each box on the board. (Rahina, 2007) stated that students would be more likely to receive information if using interesting media which provide fun learning atmosphere such as playing the snakes and ladders game.

This game does not rely on the process of message delivery from health officers, school-health-clinic teachers, or facilitators. The students could play the game independently and as often as they want, and thus they were more exposed to information in the game. Similarly, (Labibah, 2015) found the modification of this game gave a significant effect on the students' knowledge and attitudes about dental and oral health. In her study, the respondents who initially had a negative attitude turned to have a positive attitude after they knew dental and oral health. A study of (Astrianingsih N, 2014) children's knowledge and attitudes about how to prevent cerumen impaction increased after playing this game.

Every individual should have knowledge to make a change; hence, finding solutions to all health issues is more easier. On the other hand, the age difference possibly could make individuals not have adequate knowledge.

The students aged 10-12 years had the ability to capture all positive experiences from the intervention, both in terms of knowledge and emotion. They also built a belief that will eventually shapes a positive attitude on healthy behavior. The game also provides a new cognitive foundation in forming attitude to stop open defication and behave healthily. By looking at the interesting illustrations, the students could understand that open defication would impact negatively on themselves, their families and others. Messages in each box of the game are suggestive and strong enough in informing a particular behavior and forming a certain attitude. Generally, an education toll may contain positive and negative information, which will ultimately determine a person's attitude towards a particular object.

The weak cognitive components could influence the perception of how to stop open defication. People will show attitudes and changing habits after they find out information and facts about different objects and learn values associated with them. In addition, the environment becomes one of the supporting factors for changing negative to positive attitudes. Changes in attitudes and behavior are imposed on an individual. Learning is a process within the individual self and not aboutfollowing what a teacher or facilitator says. Learning in a more enjoyable atmosphere will motivate the students to make changes on their own will.

Wawan A (2010) explained good knowledge does not guarantee a person to have a positive attitude. However, more and more positive information is gathered, it will cultivate a positive attitude. In line with this statement, (Notoatmodjo, 2012) confirmed messages or materials will be better understood when teachers use teaching aids that provide engagement in human senses very. 
In short, the snakes and ladders game can be one of the solutions in introducing elementary school students to health education. It also overcomes barriers in human resources in charge of providing health education to elementary school students.

This study has presented an overview of how the snakes and ladders game and triggering increased knowledge and attitudes of elementary school students about how to stop open defication. Nevertheless, this study did not look into the behavioral change. Therefore, future studies could see from the aspect of behavioral change. Furthermore, this study only applied the treatment once, and thus the results could not be generalized.

\section{CONCLUSION}

This study concluded that there was a meaningful difference in the increase in knowledge and attitude between the control group with triggering method and the experiment group with the snakes and ladders game. The statistical results summaried that the triggering method equally improved knowledge and attitude about how to stop open defication. However, the snakes and ladders game increased knowledge and attitudes more than the triggering method. Therefore, it could be the alternative health promotional tool about environmental health for elementary school.

The snake and ladders game could also be implemented outside elementary school students in the $5^{\text {th }}$ grade. It is necessary to modify and translate information into various local languages to allow the students to have better understanding. Other health education media with different materials and topics are necessary to be developed in the future.

This study also recommended that the district health office can coordinate and cooperate with health institutions, such as primary healthcare centers and school's health clinics to implement the snake and ladders game to better gain knowledge change gradually. During the pre-tests and post-test, future studies could try to adjust the distance of each seat resulting in a more conducive situationn.

\section{REFERENCE}

Astrianingsih N, Kristiawati, K. I. (2014) 'Permainan Ular Tangga meningkatkan pengetahuan dan sikap anak Sekolah Dasar dalam pencegahan Impaksi Serumen di SDN Tambaksari III Surabaya. CMSNJ, 3(1), Hal. 64-73.

Bandung, D. K. K. (2015) 'Profil Kesehatan Kota Bandung 2015', Hal. 46.

Blakely G, Skirton H, Cooper S, Allum P, N. P. (2010) 'Use of educational games in the health professions: a mixed-methods study of educator's perspectives in the UK', Nursing and Health Science, 12, page. 2731. doi: https://doi.org/10.1111/j.14422018.2009.00479.x.

Departement of Health (2008) 'Keputusan Menteri Kesehatan RI Nomor 852/Menkes/SK/IX/2008 Tentang Strategi Nasional Sanitasi Total Berbasis Masyarakat', in. Jakarta: Menteri Kesehatan Republik Indonesia.

Green, L. K. and M. (1992) 'Health promotion planning: An educational and environmental approach', Patient Education and Counseling, 19(3), Page 298. doi: 10.1016/07383991(92)90152-9.

Gunarsa, S. D. (2008) Psikologi Praktis: Anak, Remaja dan Keluarga. Jakarta: Libri.

Hamdalah, A. (2013) 'Efektivitas Media Cerita Bergambar dan Ular Tangga dalam Pendidikan Kesehatan Gigi dan Mulut Siswa SDN 2 Patrang Kabupaten Jember', Jurnal Promkes, 1(2), Hal. 118-123. doi: 10.1002/ejoc.201200111.

Kar, K. (2005) 'Practical Guide to 
Triggering Community-Led Total Sanitation', East Asia, Hal. 1-14.

Ministry of Health (2010) 'Buku Pedoman Pengendalian Penyakit Diare', in. Jakarta: Kemenkes RI Direktorat Jenderal PP dan PL.

Ministry of Health (2013) 'Road Map Stbm', Kementerian Kesehatan RI, Hal. 65.

Labibah, A. E. (2015) 'Pengaruh Permainan Ular Tangga Modifikasi Terhadap Pengetahuan Kesehatan Gigi dan Mulut Pada Anak', Medali Jurnal, Hal. 1-4.

Lucie, permana sari D. (2006) 'Hubungan antara Alat Permainan Edukatif dan Perkembangan Motorik Anak pada Taman Penitipan Anak', Majalah Kedokteran Nusantara, 39, Hal. 2743.

Notoatmodjo, S. (2012) Promosi Kesehatan Di Sekolah. Jakarta: Rineka Cipta.

Pratiwi, D. A. and Erawan, Nani Yuniar, P. E. M. (2016) 'Pengaruh penyuluhan metode permainan educative dan metode ceramah terhadap pengetahuan, sikap dan tindakan tentang pencegahan penyakit diare pada murid SD di Kecamatan Poasia Kota KediriNo Title', JIM KESMAS, 1(2), Hal. 1-18.

Pudjaningrum, Wahyuningsih N, D. Y. (2016) 'Pengaruh metode pemicuan terhadap perubahan perilaku buang air besar sembarangan', Jurnal Kesehatan Masyarakat, 4(5), Hal. 100-108.

Tamansari Primary Health Center (2016) Profil Kesehatan 2016. Kota Bandung.

Rahina, N. (2007) 'Media Pembelajaran Berbasis Visual Berbentuk Permainan Ular Tangga Untuk Meningkatkan Kualitas Belajar Mengajar di Sekolah Dasar', Lembaran Ilmu Kependidikan Jilid 36 No.1, Hal. 35-44. doi: 10.1016/j.arcontrol.2012.09.004.

Siyam, Syarifah Nur LailiSiyam, S. N. L., Nurhapsari, A., \& Benyamin, B.
(2015) 'Pengaruh Stimulasi Permainan Ular Tangga Tentang Gingivitis Terhadap Pengetahuan Anak Usia 8-11 Tahun', ODONTO Dental Journal, 2 (1), Hal. 25-28.

Tamansari, P. K. (2015) Monografi Kelurahan Tamansari Kecamatan Bandung Wetan. Bandung.

Wawan A, D. M. (2010) Teori dan Pengukuran Pengetahuan, Sikap, dan Perilaku Manusia. Yogyakarta: Nuha Medika. 